\title{
Evaluation of Hepatotoxic effects of Leaves Extract of Cassia italica (Mill.) Lam. ex F.W. Ander (Leguminosae) in Albino Rats
}

\author{
${ }^{* 1}$ SHEHU, S; ${ }^{1}$ ABUBAKAR, AS; ${ }^{2}$ AHMED, H \\ ${ }^{I}$ Department of Biochemistry, ${ }^{2}$ Department of Biological Sciences, Faculty of Science, Usmanu Danfodiyo University, Sokoto, Nigeria. \\ *Correspondence Author Email:elmafary@gmail.com
}

\begin{abstract}
The hepatotoxic effect of aqueous leaves extract of Cassia italica on some liver function parameters was investigated in albino rats. Five groups of the rats were administered the following graded doses of the extract orally: $0,300,600,1500$ and $3000 \mathrm{mg} / \mathrm{kg}$ bw, for groups $1,2,3,4$ and 5 respectively, once daily for 28 days. The serum ALAT, ASAT and ALP levels were found to increase significantly $(\mathrm{p}<0.05)$ in all the groups when compared to the control; whereas the serum Albumin levels decreased significantly $(\mathrm{p}<0.05)$ in all the groups when compared with the control. There was also a significant increase in Total Bilirubin level $(\mathrm{p}<0.05)$ in the groups administered with 3000 and $1500 \mathrm{mg} / \mathrm{kg}$ bw, but the reverse was the case in the groups administered with 600 and $300 \mathrm{mg} / \mathrm{kg}$ bw of the extract, which showed significant decrease $(\mathrm{p}<0.05)$ when compared with the control. These results suggest that, the aqueous leaves extract of Cassia italica has adverse effects on the functional capacities of rat liver.
\end{abstract}

\section{DOI: https://dx.doi.org/10.4314/jasem.v22i9.28}

Copyright: Copyright $(02018$ Shehu et al. This is an open access article distributed under the Creative Commons Attribution License (CCL), which permits unrestricted use, distribution, and reproduction in any medium, provided the original work is properly cited.

Dates: Received: 30 August 2018; Revised: 11 September 2018; Accepted: 30 September 2018

Keywords: Hepatotoxicity, extract, Cassia italic, rats

Medicinal plants and herbs contain substances known to modern and ancient civilizations for their healing properties. A number of plants have been used in traditional medicine for many years; some do seem to work, although there may not be sufficient scientific data to confirm their efficacy (Sofowara, 1982). The medicinal value of these plants lies in some chemical substances they contain, that produce definite physiological action on the human body. The most important of these bioactive constituents of plants are alkaloids, tannins, flavonoids and phenolic compounds (Elsayed et al., 1992).

Herbal knowledge is gathered through trial and error over a period of time. Traditional herbalists detect effective substances by trying them out on themselves or on patients and therefore, toxicity and side effects may be encountered during treatment (Bandiera et al., 1999). Traditional medicines include practices, such as herbal medicine, ayurvedic medicine, unani medicine, acupuncture, as well as other medical knowledge and practices (not orthodox) all over the globe. Inappropriate use of traditional medicines or practices can have negative or dangerous effects and so, further research is needed to ascertain the efficacy and safety of the medicinal plants used in traditional medicine system (WHO, 2003).
Cassia italica, also known as Cassia obovata or Senna italica as well as 'Filasko' in Hausa language, is a perennial plant that grows abundantly in the southern part of the eastern desert and commonly used in most parts of Nigeria for the treatment of constipation, oedema and skin diseases. Phytochemical studies on aerial parts of Cassia species demonstrated the presence of $\beta$-sitosterol, stigmasterol, $\alpha$-amyrin, anthraquinone, anthrone, and probably other constituents (Acharya and Chtterjee, 1975). This study therefore, evaluated the hepatotoxicity effect of the plant's aqeous extract on rat liver.

\section{MATERIALS AND METHODS}

Experimental Animals: The study was carried out with adult albino rats, weighing $180-220 \mathrm{~g}$ of both sexes. The animals were purchased from animal house of the Department of Biological Sciences of Usmanu Danfodiyo University, Sokoto. The animals were provided with standard diet (Vital Feed) and fresh clean water ad libitum. They were allowed to acclimatize to the experimental conditions in cages for one week prior to the commencement of the experiment.

Collection of the Plant Sample: The mature leaves of Cassia italica were collected from the farmland area 
within the main campus of Usmanu Danfodiyo University, Sokoto. The plant was identified by a taxonomist in the herbarium of Botany Unit, Biological Sciences Department, Usmanu Danfodiyo University, Sokoto. Where a voucher specimen was kept for record purposes.

Preparation of Aqueous Leaves Extract: The leaves of the plant were shed dried at room temperature and then pulverized to coarse powder. $400 \mathrm{~g}$ of the powdered sample were dissolved in about 4 litres of water and left for 24 hours at room temperature. The mixture was filtered using muslin cloth after 24 hours to obtain the filtrate. The filtrate was evaporated in a drying cabinet at $45^{\circ} \mathrm{C}$ to obtain a concentrated extract. The concentrated extract was reconstituted in distilled water to obtain a known concentration of the extract (Lorke, 1983).

Acute Toxicity Studies (Determination of $L D_{50}$ ): The acute toxicity test was carried out based on OECD guideline (OECD, 2001). Five rats were randomly selected and marked to permit individual identification. The animals were weighed prior to the administration of the extract. One animal serves as the control and the four others were administered $3000 \mathrm{mg} / \mathrm{kg}$ body weight of the extract, orally in a single dose using intubation canola. Each animal was observed at the interval of one hour for the first four hours after dosing for any symptom of toxicity and subsequently for next 48 hours. The number of survivors was noted after 48 hours. The result was recorded on the basis of mortality and expressed as $\mathrm{LD}_{50}$. The animals were reweighed to determine change in weight over the 48 hours period.

Sub-chronic Toxicity Test: Repeated toxicity study was carried out according to OECD guideline (OECD, 2001). The animals were divided into five groups of five rats each. Group 1 served as control, receiving only $1 \mathrm{ml}$ of distilled water daily. Groups 2, 3, 4 and 5 were respectively administered $300,600,1500$, and $3000 \mathrm{mg} / \mathrm{kg}$ body weight of the extract, representing $10,20,50$ and $100 \%$ of the $\mathrm{LD}_{50}$, respectively. The extract was administered orally, daily for 28 days. The body weights of the animals were evaluated a day before the start of administration and then weekly for four weeks.

Collection of Blood Samples: On the $29^{\text {th }}$ day, the animals were sacrificed after overnight fast and the blood samples were collected into labeled centrifuge tubes and allowed to stand for 10 minutes before being subjected to centrifugation at $4000 \mathrm{rpm}$ for $15 \mathrm{~min}$. The serum was separated from the whole blood using
Pasteur pipette and transferred to labeled dry clean serum tubes and then kept refrigerated.

Liver Function Tests: Total Protein was determined by Biuret Method (Hiller, 1926), based on reaction of Cupric ions in an alkaline medium, which interacts with protein peptide bonds resulting in the formation of a blue-violet complex (the so-called biuret reaction). Albumin was determined by Bromocresol Green method, measured based on its quantitative binding to the indicator 3,3,5,5-tetrabromo-m cresol sulphonephthalein (bromocresol green, BCG). Aspartate Aminotransferase (AST) was determined by monitoring the concentration of oxaloacetate hydrazone formed from 2,4-dinitrophenylhydrazine (Reitman and Frankel, 1957). Alanine Aminotransferase (ALT) was determined by monitoring the concentration of pyruvate hydrazone formed with 2,4-dinitrophenylhydrazine (Reitman and Frankel, 1957). Alkaline Phosphatase (ALP) was measured based on $\rho$-nitrophenyl phosphate, which is hydrolyzed to $\rho$ - nitrophenol and inorganic phosphate by alkaline phosphatase at pH 10.4 (Kind and King, 1954).

Statistical Analysis: The results were analyzed using Analysis of Variance (ANOVA) with INstat3 software (SanDiago, USA). Values were expressed as mean \pm standard deviation $(\mathrm{SD})$. Differences in mean $( \pm \mathrm{SD})$ were considered significant at $\mathrm{p}<0.05$.

\section{RESULTS AND DISCUSSION}

The results of the studies were presented in tables 1-3. All the rats survived after 48 hours of administration of $3000 \mathrm{mg} / \mathrm{kg}$ body weight of the extract (Table 1 ). The result revealed no observable gross negative effects such as salivation, diarrhea, coma or convulsion in the rats administered the various doses of the extract. There were no changes on the skin colour or eyes, hair removal was not noticed either. All the rats had normal tail (flexible), granular excrement and would isolate themselves at the corners of the cage after dosing. There was no observable depressive effect on the central nervous system and mortality was not recorded. It could be concluded, therefore, that the $\mathrm{LD}_{50}$ for the extract is greater than $3000 \mathrm{mg} / \mathrm{kg}$ body weight.

There was a significant $(\mathrm{p}<0.05)$ decrease in the body weight of all the groups treated with the extract when compared with their initial weights before treatment. The rats in the control group gained weight when compared with their initial weights (Table 2). This suggests that the extract had adversely affected the weights of the treated rats. 
There was a significant $(\mathrm{P}<0.05)$ increase in ALAT in the rats administered $3000 \mathrm{mg} / \mathrm{kg}$ bw and $1500 \mathrm{mg} / \mathrm{kg}$ bw when compared with the control (Table 3). However, a significant $(\mathrm{p}<0.05)$ decrease in ALAT was observed in the rats administered $600 \mathrm{mg} / \mathrm{kg}$ bw and $300 \mathrm{mg} / \mathrm{kg}$ bw of the extract, suggesting that there was no adverse effect on the liver at these concentrations. The dose-dependent elevations observed in the serum enzymes in the groups administered $3000 \mathrm{mg} / \mathrm{kg}$ bw and $1500 \mathrm{mg} / \mathrm{kg}$ bw indicates possible hapatocellular damage (Sigma Diagnostic, 1985). There were significant $(\mathrm{P}<0.05)$ increases in ASAT and ALP when compared with the control in all the treated groups (Table 3). Increase in the activity of these enzymes in the plasma is often seen following liver damage and it is attributable to the loss of the enzyme from damaged hepatocytes rather than increased production (Tilkian, 1979). This also suggests that other non-specific tissue damage could have occurred as these enzymes have a wider tissue distribution beyond the liver (Boyd, 1988). ALAT and ASAT are liver specific enzyme markers of necrotic injury and cholestasis (Lott and Wolt, 1986). Total bilirubin significantly $(\mathrm{p}<0.05)$ increased in animals administered $3000 \mathrm{mg} / \mathrm{kg}$ bw and $1500 \mathrm{mg} / \mathrm{kg}$ bw respectively, but significantly $(\mathrm{p}<0.05)$ decreased in animals administered $600 \mathrm{mg} / \mathrm{kg}$ bw and $300 \mathrm{mg} / \mathrm{kg}$ bw of the extract (Table 3). The significant increase in total bilirubin in animals administered $3000 \mathrm{mg} / \mathrm{kg}$ bw and $1500 \mathrm{mg} / \mathrm{kg}$ bw suggests that the extract had adversely affected the excretory function of the liver. However, the decrease in bilirubin levels in animals administered $600 \mathrm{mg} / \mathrm{kg}$ bw and $300 \mathrm{mg} / \mathrm{kg}$ bw of the extract may be attributed to the depressant effect of the extract (Odutola, 1992).

Albumin significantly $(\mathrm{P}<0.05)$ decreased in all the treated groups when compared with the control (Table $3)$. Significant decrease in albumin in all the treated groups suggests that both the excretory and synthetic functions of the liver were altered as these are markers of liver excretory and synthetic functions (Weiss et al., 1983).

Table 1: The effect of administration of acute dose $(3000 \mathrm{mg} / \mathrm{kg} \mathrm{bw})$ of aqueous leaves extract of Cassia italica on the behavior of the

\begin{tabular}{lllll}
\multicolumn{5}{c}{ albino rats. } \\
\hline Animals & 0 -5min & 6-30min & 31-59min & 1-48 hrs \\
\hline Rat -1 & Restlessness & Mouth scratch & Calm & Normal \\
Rat -2 & Restlessness & Mouth scratch & Weak & Normal \\
Rat -3 & Restlessness & Mouth scratch & Weak & Normal \\
Rat -4 & Restlessness & Mouth scratch & Weak & Normal \\
Rat -5 & Restlessness & Mouth scratch & Sleep & Normal \\
\hline
\end{tabular}

Table 2: The effect of four weeks administration of gradedt doses of aqueous leaves extract of Cassia italica on total weight of albino rats.

\begin{tabular}{llllll}
\hline Dose (mg/kg) & Initial weight & Week1 & Week2 & Week3 & week4 \\
\hline 0 (control) & $135.4 \pm 19.45$ & $137.2 \pm 19.40$ & $139.4 \pm 22.35$ & $139.2 \pm 22.60$ & $155.2 \pm 23.83$ \\
3000 & $153.2 \pm 2.39$ & $152.0 \pm 15.52$ & $153.4 \pm 16.33$ & $148.6 \pm 15.37$ & $135.4 \pm 13.83$ \\
1500 & $179.2 \pm 3.42$ & $171.2 \pm 7.92$ & $169.4 \pm 5.94$ & $165.2 \pm 06.98$ & $165.4 \pm 7.23$ \\
600 & $143.6 \pm 4.04$ & $127.4 \pm 15.85$ & $127.6 \pm 17.85$ & $124.0 \pm 20.58$ & $112.0 \pm 23.96$ \\
300 & $163.0 \pm 1.58$ & $153.4 \pm 2.88$ & $156.8 \pm 6.58$ & $154.6 \pm 6.77$ & $157 \pm 8.27$ \\
\hline
\end{tabular}

Values were expressed as mean \pm standard deviation $(n=5)$.

\begin{tabular}{|c|c|c|c|c|c|}
\hline Dose (mg/kg) & ALAT (U/I) & ASAT (U/I) & $\operatorname{ALP}(\mathbf{U} / \mathbf{I})$ & Albumin (g/dl) & Total bilirubin (mg/dl) \\
\hline 3000 & $72.92 \pm 2.32^{*}$ & $201.80 \pm 2.67^{*}$ & $197.5 \pm 1.00^{*}$ & $4.29 \pm 0.54$ & $1.37 \pm 0.32^{*}$ \\
\hline 600 & $52.82 \pm 3.32$ & $168.12 \pm 1.18^{*}$ & $152.18 \pm 2.56^{*}$ & $2.64 \pm 0.38$ & $0.73 \pm 0.04$ \\
\hline 300 & $44.52 \pm 4.16$ & $153.73 \pm 3.54^{*}$ & $133.77 \pm 1.68^{*}$ & $2.03 \pm 0.43$ & $0.67 \pm 0.08$ \\
\hline
\end{tabular}

Conclusion: In the light of the foregoing, it is evident that the aqueous leaves extract of $C$. italica had adverse effects on the liver function in the treated rats, which were however, dose dependent. The liver function was impaired at higher doses while at therapeutic dose the leaves extracts of $C$. italica could be used to manage constipation, oedema and skin infections with an acceptable margin of safety.

\section{REFERENCE}

Acharya, TK.; Chatterjee, I.B. (1975) Isolation of chrysophanic acid -9 anthrone, the major antifungal principle assia tora. Lioydia 38: 218-20

Bandiera, SO., Albano, G.; Barbos, F.M. (1999). Diversity and uses of plant species in Africa with emphasis on trees and shrubs. $429-439$. 
Elsayed, NH. et al., (1992). Flavonoids of Cassia italica. Phytochemistry 31(6): 2187.

Hiller, A. (1926). Biuret Method. Proc. Soc. Exp. Biol. And Med., 24:385.

Kind, PR.; King, EJ. (1954). Estimation of plasma phosphatase by determination of hydrolysed phenol with amino antipyrine. J. Clin. Pathol., 7: 322-326.

Lorke, D. (1983). A new approach to acute toxicity testing. Arch. Toxicol. 54: 275 - 287.

Lott, JA.; Wolt, PL. (1986). Alanine and Aspartate Amino transferase. Clinical. Enzymology New York. Field Rich and Associates. $111-138$

Odutola, AA. (1992). Rapid interpretation of Routine clinical laboratory Test. Asekome, S. and Co. Zaria. 1 - 30 .

OECD, (2001). Guidelines for testing of chemicals acute oral toxicities - up and down procedure. 425: 1 -26
Reitman, S.; Frankel, S. (1957). A colorimetric method for the determination of serum glutamic oxalocetic and glutamic pyruvic transaminases. Amer. J. Clin. Pathol; 28: 56 63.

Sigma Diagnostics, (1985). Transaminases (ALT and AST) Quantitative colorimeter determination in serum, plasma or cerebrospinal fluid procedure.

Sofowora, EA. (1982): Medicinal plants and traditional medicine in Africa. $1^{\text {st }}$ ed. 142 149.

World Health Organization, WHO (2003). Traditional medicine.

Weiss, I.; Gautam A.; lanff, J. (1983). The clinical importance of a protein bound fraction of serum bilirubin in patient with hyperbilirubin. N. Eng. J. med; 309: 147 - 150. 